\title{
A PEDAGÓGUSKÉPZÉS ÉS A SZAKKÉPZÉS ÚJ ÖSSZEFÜGGÉSEI
}

\author{
BENEDEK ANDRÁs* - LÖRINCZ ÉVA ANNA ** \\ *a Budapesti Müszaki és Gazdaságtudományi Egyetem Gazdasági \\ és Társadalomtudományi Kar Műszaki Pedagógia Tanszékének \\ egyetemi tanára \\ benedek.a@eik.bme.hu \\ ** a Budapesti Műszaki és Gazdaságtudományi Egyetem Gazdasági \\ és Társadalomtudományi Kar Müszaki Pedagógia Tanszékének \\ egyetemi tanársegédje \\ lorincz.e@eik.bme.hu
}

\begin{tabular}{l}
\hline Jelentős fordulóponthoz érkezett a hazai pedagógusképzés átalakitása, mely az általános \\
feladatok mellett sajátos kérdésekre is keresi a válaszokat. E problémakör lényeges eleme \\
a szakképzési rendszer által igényelt és foglalkoztatott pedagógusok képzésének sajátos- \\
ságai, amelynek történetisége, intézményi sajátosságai a fejlödést jelentösen meghatáro- \\
zó tényezök. A tanulmány ezzel az összetett témakörrel, a kihívásokat és lehetöségeket \\
komplexen mérlegelve foglalkozik a pedagógusképzés általános és a szakképzés sajátos \\
jellemzöinek rendszerezése alapján. A szerzök kísérletet tesznek a képzési folyamat föbb \\
szakaszainak a leírására, továbbá a szakmai pedagógusképzésre jellemzö progressziv tö- \\
rekvések szemléltetésére ismertetik a Budapesti Müszaki és Gazdaságtudományi Egyete- \\
men megvalósult szolgáltató és kutatóhálózat kialakitására irányuló projektet.
\end{tabular}

\section{Bevezető}

Az oktatáspolitika „magasságában” és a gyakorlat mindennapi valóságában a közoktatás és felsőoktatás sajátos metszéspontjában van a PEDAGÓGUS. Igen a nagybetüvel írt pedagógus, mint egy sajátos hivatásmodell alanya, és mint jelentős - a társadalom minőségét meghatározó - humán tényező. Humán, de ugyanakkor gazdasági tényező is, mely az oktatás és különösen a szakképzés hatékonyságát képes pozitív és negatív értelemben is befolyásolni. A foglalkozás és hivatás összefüggésrendszere, a tényleges, számos elemében lehangoló mindennapi gyakorlat, a pedagógusképzés témakörét nem csupán változatlan időszerüséggel ruházza fel, hanem a szerzők véleménye szerint új felismerésekhez is vezet. Jelen írás a pedagógusképzés rendszerébe illesztve tekinti át a szakképzés pedagógusképzésre (döntően a szakmai pedagógusképzésre) gyakorolt hatását, $\mathrm{s}$ vázolja fel azt az új összefüggésrendszert, mely a következő évekre az átalakulás és fejlődés szakmai kereteit alkotja. Írásunk részben kísérlet a képzési folyamat főbb szakaszainak leírására, részben egy példa: a szak- 
mai pedagógusképzésben a minőségorientált hálózati struktúrák kiépülését szemléltető modell ismertetése.

\section{Kihívások és lehetőségek}

A hazai oktatáspolitika, a szabályozási-jogalkotási gyakorlat az utóbbi negyedszázadban csak részlegesen volt képes a Philip H. Coombs (1971) által már a múlt század hatvanas éveiben megfogalmazott oktatási válságból való kilábalást és a fejlődést korszerü jogi keretek közé helyezni. Magyarországon az 1985-ös közoktatási törvény, bár sokat tett az iskolák szakmai önállóságának, a pedagógusok tevékenységének nyitottabb keretekbe szervezése érdekében, a differenciált irányítási rendszer kiépülését kezdeményezve, azonban az oktatási-nevelési rendszerünk müködése - éppen a nemzetközi összehasonlító elemzések alapján - nem igazolta számos intézkedés előzetesen feltételezett pozitív hatását. Az 1993-as közoktatási és szakképzési törvény, jelentős társadalmi várakozás által kísérve, tovább differenciálta az oktatásügy intézményi és müködési rendszerét. A tartalmi szabályozásnak új elemeit vezette be, emellett a gazdasági helyzet is jelentősen befolyásolta, hogy az egyre bonyolultabb jogi szabályozás és a folyamatos korrekciók az elmúlt másfél évtizedben jelentősen erodálták az oktatási-nevelési intézményrendszert. Eközben a mély társadalmi változásokra, különösen azok negatív hatásaira - például elszegényedés, szegregáció, növekvő agresszió - a törvénykezés nem igazán reagált, így a nevelési rendszer keretei között adós maradt többek között a pedagógusokat támogató szabályozási elemek kidolgozásával.

Az ezredforduló óta a szakmai kihívások egyre markánsabban jelentkeztek, s határozottan érzékelhetővé vált, hogy fordulatra van szükség a nevelés-oktatás világában. Általánossá vált az a felismerés, hogy szükség van a társadalom értéksokszínűségéhez, az értékközvetítés feladataihoz és intézményrendszeréhez, valamint az ösztönzők rendszeréhez igazodó új, átfogó szabályozásra. A válasz keresése során látható, hogy a hazai neveléssel kapcsolatos mai kihívások megfogalmazása nem könnyü feladat, bár a pedagógus szakma egyetért abban, hogy az ezredfordulót követő magyar pedagógiai közgondolkodásban a képzés szerkezeti és tartalmi megújításával kapcsolatos problémakörök jól érzékelhetőek. Ezt tágabb összefüggésben szemlélteti, tárgyalja több átfogó értékelésre alapozott stratégiai jelentőségü dokumentum (Fazekas et al., 2008; Csermely et al., 2009; Benedek és Hunyadyné, 2009). Az eltérő müfaji sajátosságok ellenére mindegyik mü tárgya, lényege és a szerzők törekvése a következőkben foglalható össze: a magyar oktatás és nevelési rendszer helyzetének önkritikus elemzése, valamint javításának ösztönzése. Azonos a munkákban az is, hogy az új évezred első évtizedét a válság elmélyüléseként szemlélik, $\mathrm{s}$ a nevelésügy szempontjából a válságból való kilábalás útjainak keresését emelik ki. Az új kihívások áttekintése során megállapítható, hogy a pedagógiai kihívások meglehetősen szemléletes struktúrát alkotnak. Jellegzetes problematikának tekint- 
hetők azok a társadalmi változások a nevelésügy nézőpontjából, melyek az előző két évtizedben végbement történelmi változásokkal hozhatók összefüggésbe. Ezek a változások (privatizáció, munkanélküliség, nemzeti szuverenitás, európai integráció) nem hagyták érintetlenül az életünket meghatározó intézményeket és viselkedési normákat, a társadalom tagjait összefüző kötelékeket sem.

Az elmúlt negyed században jelentősen átalakult a magyar társadalom rétegződése, aminek nyertesei és vesztesei egyaránt voltak. A magyar társadalom sok szempontból érzékelhető tagoltsága különösen drámai: a különböző érdekekkel rendelkező és eltérő normákat követő rétegek és csoportok, illetve az őket képviselő szervezetek közötti érdekkonfliktusok eröteljesen jelen vannak. Különösen szembetűnő, hogy mennyire megváltozott az egyének és a közösségek kapcsolata:

- Az egyének nem ugyanolyan módon és nem ugyanolyan mértékben várják és várhatják a közösségtől, mint korábban, hogy az biztonságot nyújtson számukra.

- Az egyének sokasága számára vált nyilvánvalóvá az öngondoskodás szükségessége.

- A verseny az egyéni és a családi lét kikerülhetetlen valóságává vált. Az együttmüködésnek és a szolidaritásnak új, a korábbiaktól alapvetően eltérő formái alakultak ki.

Az ezredfordulót követő évtizedben kétségtelenül mélyülő gazdasági és társadalmi válság ösztönözte világszerte azokat a vizsgálódásokat, melyek hazai megjelenésére a fentiekben utaltam. Míg a Zöld Könyv (2008) és a Szárny és Teher (2009) esetében viszonylag szük szakmai csoport foglalkozott az oktatás és nevelés kérdéskörével, a VII. Nevelésügyi Kongresszus (2008) szervezői - egyébként azonos célok által vezérelve - nem csupán a pedagógus szakma, az óvodák, az iskolák, a kollégiumok szakembereinek találkozóját kívánták megszervezni. Az előkészítés folyamata - hasonlóan, mint az Oktatás és Gyermekesély Kerekasztal esetében - olyan programot kínált, amelyhez a magyarországi társadalom számos szakmai csoportja kapcsolódhatott érdeklődéssel, hozzászólási szándékkal. A kongresszus lehetőséget adott arra, hogy a nevelésügy megmutassa magát a társadalomnak, $\mathrm{s}$ a társadalom megfogalmazza, hogy mit vár a nevelés-oktatás intézményeitől, érdeklődése középpontjában a gyermekek és a fiatalok nevelése állt, ugyanakkor nyitott volt a tanulás minden formájára, így az egész életen át tartó tanulásra és a szakmai képzés vagy a munkavégzés során zajló tanulásra is.

\section{A szakmai tanárképzés történeti gyökerei}

Magyarországon sajátos történetiséggel rendelkezik az egyetemi szintű szakmai tanárképzés, melynek formálódása különösen a müszaki képzés esetében modellértékü. A tanárképzés intézményes keretei Eötvös József minisztersége idején alakul- 
tak ki: 1870-ben létrehozták a tanárképző intézeteket/tanárképezdéket. 1871-ben kezdte meg müködését a reáltanodai tanárképezde a Királyi József Müegyetemen, amelynek fontosságát jelzi, hogy első vezetöje a Mủegyetem első rektora, Stoczek József professzor volt. A középiskolai tanárképzésben további lényegi változást jelentett az 1924. évi XXVII. törvény, amely az elméleti tanárképzést a tudományegyetemi feladatokhoz rendelte, s szervezeti háttérként az egyetemek mellett müködő tanárképző intézeteket jelölte ki. Ez a törvény a tanári képesítést a kötelező tanárképző intézeti tagsághoz és azzal járó követelmények teljesítéséhez kötötte. 1929-ben került elsőként kiadásra az a szabályzat, amely elöírta a tanárjelöltek gyakorlati képzését, a már korábban létrehozott gyakorlóiskolai müködést is szabályozva. 1898-ban alakult meg az Állami Kereskedelmi Iskolai Tanárképzö Intézet, amely a Királyi Magyar Tudományegyetemen 1920-ban létrehozott Közgazdasági Kar kereskedelmi osztályának részeként, a kereskedelmi szakosztály kötelezően előírt tanítási tervéhez és vizsgarendjéhez illeszkedve müködött, 1928-tól önálló kereskedelmi gyakorló iskolával. A kereskedelmi iskolai tanárképzés mellett a gazdasági fejlődés kikényszerítette az ipari és a mezőgazdasági szakoktatási intézmények új szervezeteinek létrehozását, ehhez kapcsolódóan az ipari és a mezőgazdasági tanárképzést is. A kereskedelmi, ipari és mezőgazdasági tanárképzés összefoglaló néven, mint gazdasági szakiskolai tanárképzés egy 1934. évi törvény nyomán a József Nádor Müszaki és Gazdaságtudományi Egyetem feladata lett.

A II. világháborút követően 1948-ban megszüntették az egyetemi szintü müszaki tanárképzést, s tízhónapos gyorsképzés, majd három éves főiskolai képzés lépett a helyébe. Az átmeneti szervezeti megoldásokat követően az intézményi bázist a Budapesti Müszaki Egyetemen (BME) az 1961-ben létrehozott Pedagógia Tanszék, majd az 1971-ben szervezett Tanárképzö és Pedagógiai Intézet jelentette. A mai magyarországi szakmai pedagógusképzés személyi állománya döntő módon e képzésben vett részt, részben itt szerzett fokozatot, illetve az itt végzettek adtak vezetőket azoknak az intézményeknek ${ }^{1}$, melyek az utóbbi évtizedekben a szakmai pedagógusképzés színes intézményrendszerét alkották, alkotják. A jelenlegi helyzet: 1995től az intézeti tanszékek önállóvá válásával, a Müszaki Pedagógia Tanszék (MPT) végzi a müszaki pedagógusok képzését. 2005-től a tanszék az Alkalmazott Pedagógia és Pszichológia Intézet keretein belül müködik. Jelenleg a BME Gazdaság és Társadalomtudományi Karán müködő tanszék a müszaki és közgazdasági szakképző iskolák számára képez tanárokat, valamint szakirányú továbbképzéseket szervez a pedagógus-továbbképzési rendszerhez kapcsolódóan. A graduális képzésre felvett hallgatók előképzettségük alapján (nappali és levelező tagozaton) mérnöktanári, közgazdásztanári oklevelet szerezhetnek. A müszaki szakoktatók három éves levelező képzés keretében pedagógiai képesítéshez juthatnak.

\footnotetext{
${ }^{1}$ Az elmúlt három évtizedben jelentős műszaki szakmai tanárképzési intézményfejlesztés folyt az Óbudai Egyetemen, a Széchenyi Egyetemen, a Dunaújvárosi Főiskolán, illetve elődintézményeikben.
} 
Az ezredfordulót követő évtizedben a társadalmi párbeszéd egyik fontos témája volt, hogy a hazai szakképzés sokat veszített presztízséből, hogy számos szakmában minimálisra csökkent a képzésben részt vevők száma. E jelenségek erőteljesen hatottak arra, hogy a szakmai tanárképzés hallgatói létszáma visszaesett, a nappali tagozatos képzés leépült és a levelező képzés vált általánossá. S ahogy lenni szokott a kritikai kijelentések egyre inkább igazolódtak, a középfokú szakképzés az oktatási rendszer válságágazatává vált. Az állam, sikertelenségét beismerve, e területen lehetőséget adott a gazdasági kamarák fokozott szerepvállalására, $\mathrm{s}$ célként deklarálták a közel száz éve Németországban bevezetett (azóta számos esetben jelentősen megújított) duális szakképzési modell megvalósítását. E modell, illetve annak minden szakképzési problémát megoldó hatásában való hit, új horizontot rajzolt fel a magyar gazdaság számára létfontosságú és a szociális problémák kezelésében is jelentős feladatokat vállaló szakképzés átalakulásában.

A magyar szakképzés gazdasági és társadalmi feltételei és meghatározó tényezői, különösen a rendszerváltozást követő évtizedekben, bonyolult összefüggésekben jelennek meg. A képzésben résztvevők életkora, szociális helyzetükkel is összefüggő motivációjuk s az adott térség-régió foglalkoztatási környezete számos esetben nem mutatott, nem is mutathat ideális összképet. E vonatkozásban a 16 éves tankötelezettség egyidejüleg jelent erős késztetést és lehetőséget. A fejlett vállalati és technológiai kultúrával rendelkező piaci szervezetekben joggal feltételezhetö, hogy a képzési kapacitások és lehetőségek elsősorban a magasabb tudásra építhető szakmákban kínálnak az új megoldásokat. A szakmunkásképzés évtizedek óta szembesül a hátrányos helyzetü fiatalok iskoláztatásának problematikájával és/vagy a lassabban, a megfontoltabban tanulók számára hatékony pedagógiai cselekvési programok szükségességével. Ugyanakkor mintegy másfél évtizede a tankötelezettség expanziója, valamint a 16 éves korig tartó, csupán az általános képzést megengedő kerettantervi konstrukciók sajátos pedagógiai „melegedőkké” tették éppen azokat az iskolákat, melyekben előzőleg a kéz és a mozgás szakmai kultúrájára nyitott, szakmai gyakorlatokkal megnyerhető fiatalok képesek voltak a kézmüves és gyakorlatigényes ipari szakmákat elkötelezetten elsajátítani. Közben e meglehetősen ellentmondásos állapotban számos fejlesztési program - több-kevesebb sikerrel próbálta az iskolák megtartó erejét javítani, olyan eljárásokkal és szervezeti megoldásokkal segíteni, melyek képesek a 25-28 százalékos lemorzsolódással küzdő szakiskolákban kialakult pedagógiai feszültségeket enyhíteni. A fö cél, hogy elkerülhetővé váljék, ha korlátozott mértékben is, az iskolából történő kényszerü, végzettség, kvalifikáció nélküli kikerülés, általánosabban az a társadalmi-gazdasági trauma, amely generációk számára a tartós inaktivitás kényszerét jelenti.

A szakképzésben és az ehhez kapcsolódó pedagógusképzésben a fordulat elkerülhetetlen, hiszen a gazdaság szakképzési szerepvállalása számos elemében új helyzetet és új lehetőséget teremtett. A gyakorlati képzés súlyának, arányainak emelése valóban praktikus irányt jelent. De jelent-e garanciát azokra a szociális és pe- 
dagógiai problémákra, melyek a fejlett világ és a tudásra komoly igényt támasztó piacgazdaság mindegyikében az iskoláztatás stabilitását és a leszakadás megakadályozását egy időben köti olyan intézkedésekhez és intézményekhez, melyek a társadalom egészének a tudásszintjét az iskolázottság szintjének emelkedéséhez, valamint a lemorzsolódás mértékének visszaszorításához kapcsolja? E kérdésre azonnali választ adni szinte lehetetlen. A folyamatok változási trendjei az iskolázottsági mutatókban, lemorzsolódási arányokban, foglalkoztatási rátában, a kvalifikációkhoz közvetlenül kapcsolható teljesítmény és bérstatisztikákban jelennek meg, illetve ragadhatók meg.

A szakképzés, mint pedagógiai tevékenység nem csupán gazdasági mérlegelés tárgya. Annak ellenére sem, hogy a vállalatok igénye nem ezt hangsúlyozza: több gyakorlati képzés, kevesebb elméleti oktatás. Németországban sikerrel müködik az úgynevezett duális szakképzés, amely alapvetően a vállalatoknál zajló gyakorlati képzésre épül, amit csak kiegészít a szakképzési intézményekben folyó elméleti oktatás. Noha a rendszer adaptálását már elkezdték a hazai szakmai érdekképviseletek, napjainkra mégis egyre nyilvánvalóbb, hogy a magyarországi vállalatok versenyképessége már csak a szakképzés rendszerének teljes átalakításával biztosítható. Szükséges továbbá a vállalkozói utánpótlást biztosító fiatalok vállalkozói képességeinek, tudásának növelése, a pozitív vállalkozói szemlélet és kultúra formálása már az általános iskolától kezdve. A gyakorlatorientált vállalkozásoktatást el kell terjeszteni a szakközépiskolákban és a felsőoktatásban is, hogy a fiatalok akár az iskola elvégzését követően, akár néhány év rutin megszerzése után képesek legyenek saját vállalkozást indítani. Jelenleg ezen a téren nagyon gyengén állnak a hazai oktatási intézmények, így központi program kellene a hazai vállalkozásoktatás fejlesztése érdekében. A magas hozzáadott értékü iparágak fejlesztéséhez (egészségipar, high-tech, innováció, $\mathrm{K}+\mathrm{F}$, zöld gazdaság) szükség van a hazai természettudományos és mérnökképzés megerösítésére.

\section{A pedagógusképzés mai helyzete - szintek és formációs szakaszok}

A pedagógusképzés szerkezeti átalakulása elkerülhetetlennek látszik napjainkban. A kihívás ebben a folyamatban, hogy ne vesszen el a felsőoktatási kutatói mühelyek, tudományos iskolák változatossága, fennmaradhasson több pedagógiai paradigma alapkutatása és müvelése is. A pedagógusképzés és az iskolai gyakorlat közötti csatornákat feltételezhetően indokolt szélesíteni (például bázisiskolai rendszer, tanárcsere-program, kutatótanár-program). A differenciálódó, a szakirányú továbbképzések rendszerével szoros összhangban lévő pedagógusképzésben indokoltan kapjanak helyet a ma iskolája által igényelt új müveltségterületek (játék, színjátszás, drámapedagógia, hon- és népismeret), illetve a nevelést támogató ismeretkörök és eszközrendszerek (családpedagógia, konfliktuspedagógia, agresszióke- 
zelés), valamint a családdal (ez valóban a szociológia kitüntetett kutatási terepe!) kapcsolatos ismeretek (családpedagógiai-szociológiai ismeretek).

A változás egyik lényeges dimenziója a pedagógusképzés átalakítása, mely hosszú és összetett képzési rendszer, s melynek sikeres kialakítása tartósabbá és minőségében a mainál lényegesen kedvezőbbé formálhatja a pedagógusok foglalkoztatását. E folyamatban a pedagógusképzés a megszokott megközelítésnél jóval tágabb értelmezést kap, ti. a képzés előtti és utáni „,pályaszakaszokhoz” kapcsolódóan komplex rendszerré válik, amelyben a szerzők véleménye szerint a következö szakaszok formálódnak:

- Orientációs szakasz. E szakasz lényeges sajátossága a pedagógusképzést megelőzö szakmai-társadalmi kommunikáció, melyben tényszerủen bemutathatók a pedagógusképzés tartalmi-szervezeti sajátosságai, a képzési vertikum meghatározó szakaszai és a pedagógusok alkalmazásához kapcsolódó jövedelmi és karrier lehetőségek. Bár e szakaszban a szakmapolitikai kommunikáció központi feladat, azonban a pedagógusképző intézmények szerepvállalása, különösen a képzési keretszámok és kapacitások optimális összehangolása, a jelentkezők korrekt tájékoztatása és megnyerése is kiemelt jelentőséggel bír.

- Képzési szakasz. E tradicionális, a felsőoktatás számára kitüntetett szakasz lényegi sajátossága, hogy eddigi relatív zártsága számottevően oldódik. Az orientációs szakasz kapcsolódásának hiánya vagy gyengesége - szakmai érdektelenség, a képzéssel kapcsolatos motiválatlanság - alapvetỏen veszélyezteti a képzés sikerét. E szakasz nyitott jellege ugyanakkor nem csupán az orientáció sikerességét jelző keretszámokban és ténylegesen felvett hallgatói létszámokban szemléltethető, hanem azzal a kapcsolatrendszerrel és szervezeti differenciálódással, mely a hallgatók egy éves időtartamra bővülő gyakorlati képzését jellemzi majd a jövőben. A felelősség a felvételre jelentkezők orientációjától a felsőoktatási intézmény keretében szervezett képzésen át a gyakorlati képzés sokpartneres intézményi formáinak múködtetéséig terjed, s ez új, komoly szakmai és szervezési kihívás elé állítja a pedagógusképző intézményeket.

- Gyakorlat, iskolai színtér. E szakasz (komplex értelmezésben: gyakorlati képzés oktatási/felnőttképzési intézmény) jelentősége szakmapolitikai és jogi szabályozási eszközök által meghatározott. Alapvetően a felsőoktatási intézmény feladata, hogy erre a sajátos pedagógiai jellegü munkahelyi szocializációs szakaszra felkészítse a leendő pedagógusokat. A szakmai tevékenység alapvető színtere az iskola, ami a következő időszakban már a hallgató jogviszonyt követő foglalkoztatási jogviszony tényleges színtere lesz, vagyis olyan oktatási intézmény - jogokkal és kötelezettségekkel -, amely hosszabb távra biztosítja a pedagógus tevékenységének intézményi kereteit. E folyamatban jelenik meg a hosszú távú stratégiák formálójaként 
a pedagógus életpálya-modell. E fontos szabályozó mechanizmus egyik lényeges szakmai szereplője például a mentor, aki a pályakezdő pedagógus munkáját, beilleszkedését segítő, ilyen irányú szakvizsgával rendelkező, mesterpedagógus fokozattal rendelkező pedagógus ${ }^{2}$.

A pedagógusképzés teljes megújulásával, az új életpálya-modell szakmai hatásaival összefüggő várakozás érthető és jogos, különösen annak fényében, hogy az új felvételi folyamatok, azon belül az alkalmasság megítélésének kérdésköre, a változó keretszámok és a hallgatói támogatás új rendszere mélyen érinti a pedagógusképzés egészét. Ennek fényében az általánosan értelmezett orientációs szakasz, vagyis az a pedagógusképzést megelőző szakmai-társadalmi kommunikáció, melyben tényszerủen bemutathatók a pedagógusképzés tartalmi-szervezeti sajátosságai, a képzési vertikum meghatározó szakaszai és a pedagógusok alkalmazásához kapcsolódó jövedelmi és karrier lehetőségek, különösen fontos része a szélesen értelmezett pedagógusképzésnek. Az orientációs szakasz stratégiai jelentőségére, az e szakaszhoz kapcsolódó szakmai feladatok fontosságára azért kell kiemelten utalni, mert az évtizedes léptékủ folyamatok, társadalmi és intézményi beidegződések megváltoztatása értelemszerúen hosszú, többéves folyamat. Nem kevesebbről van szó ugyanis, mint a pedagógusképzés társadalmi-szakmai presztízsének jelentős emeléséröl, a képzés maradékelvü kezelésének megváltoztatásáról. E folyamatban a pedagógusképző intézmények, nyilvánvalóan megvívva belső saját intézményi helyzetükkel összefüggő csatáikat, alapvetően partnerek a változtatásban, ugyanakkor e téren a szakmai kezdeményezések ösztönzése, a társadalmi kommunikációs lehetőségek megteremtése a kormányzati adminisztráció kezében van.

A progresszív nemzetközi törekvések közül lényeges kiemelni az Európai Unió Oktatás Képzés 2020 stratégiáját $^{3}$, amelynek fő elvei, sajátosságai: Általános gyakorlattá kell tenni a tanulók, a tanárok és a tanárképzésben oktatók mobilitását az egész életen át tartó tanulás egyik alapvető elemeként. Az alapkészségek szintjének emeléséhez biztosítani kell a tanítás magas színvonalát, a megfelelő tanári alapképzést, a tanárok és az oktatók folyamatos szakmai fejlődését, továbbá a tanítást vonzó pályává kell tenni. Fontos az oktatási és képzési intézmények irányításának és vezetésének javítása, valamint a hatékony minőségbiztosítási rendszerek kialakítása. Szintén alapvető fontosságú a pályakezdő tanárok kezdeti gyakorlatszerzésben való támogatása, valamint az egyéb oktatói személyzet szakmai továbbképzési lehetőségeire való összpontosítás (például pályaorientációs szakemberek, pedagógiai asszisztensek továbbképzéseire).

\footnotetext{
${ }^{2}$ A mesterpedagógus fokozat csak 2016-tól kezdődően kötelező feltétel, ugyanakkor már a jelenlegi képzési és továbbképzési programokra jelentős hatást fejt ki.

${ }^{3}$ http://eur-lex.europa.eu/LexUriServ/LexUriServ.do?uri=OJ:C:2009:119:0002:0010:HU:PDF
} 
Magyarországon a pedagógus életpályamodellhez kapcsolódóan szükség van olyan egységes képzési, továbbképzési rendszer kialakítására, amely az alapképzést, a bevezető támogatási rendszert és a folyamatos szakmai fejlődést koherens rendszerré szervezi. Éppen a szakmai karrier szempontjából jelentős szakaszok, vagyis az előmenetel jogi és szakmai feltételekkel meghatározott lépcsői lehetnének alkalmasak arra, hogy a pedagógus továbbképzés és ebben a felsőoktatási intézmények szerepvállalását az újabb funkciók szempontjából megvizsgáljuk. A folyamatos és a törvény által is időkeretekhez kötődő továbbképzés a szakmai pedagógusok számára is lehetőség a fejlődésre és a formális előrelépésre. Ezt szemléltetendő mutatjuk be a Budapesti Múszaki és Gazdaságtudományi Egyetem Alkalmazott Pedagógiai és Pszichológiai Intézet keretében, az Új Magyarország Fejlesztési Terv Társadalmi Megújulás Operatív Program támogatásával megvalósított projektet. „A szakmai pedagógusképzést segito" szolgáltató és kutatóhálózatok kialakitása" projekt egyik példája a szakmai pedagógusképzés új fejlesztési modelljének, melynek célja a pedagógusok pályán tartása, az indokolatlan pályaelhagyások mérséklése.

\section{Egy új projekt a szakmai tanárképzésben}

Napjainkban jelentős tudományos és oktatási fejlesztések egyértelmüen jelzik, hogy a nemzetközileg is elismert sikerek együttmüködésre épülnek a tudományban (kutatói közösségek nyerik a jelentős díjakat, sokszerzős és sok intézmény kooperációjára épülnek a kiemelkedő publikációk) és az oktatásban (hálózati és intézményi szövetségek eredményesek nemzetközi összehasonlításban) is. Egyre inkább felismerik azt is, hogy az új hálózati konstrukciók nem spontán módon formálódnak, és a szakmai partnerség által - az elméletileg is igazolt tendenciák felismerésén túl -, új minőséget hordoznak. Barabási Albert László (2008) kutatásai a komplex hálózatok emberi tevékenységre jellemző működési módjait tárta fel, s kiemelte a sokáig hitt spontaneitás mögött meghúzódó kiszámíthatóságot, ami jó alapot teremtett arra, hogy az élet számos színterén a hálózati fejlődésről újszerü módon gondolkozzunk. E gondolat részben az oktatásban is formálódott, illetve az utóbbi években éppen egyre tudatosabban befolyásolta az oktatási rendszer fejlődését.

Ha a szakmai pedagógusok képzésével foglalkozó intézményrendszert, mint egy sajátos hálózatot szemléljük, akkor megállapítható, hogy nem tekinthető egyenletes elosztású hálózatnak, a kapacitások vonatkozásában jelentős különbségek vannak. A különbségek részben területi-regionális jelleg szerint, részben az intézményi környezet sajátosságai és az intézményi átalakulások mentén érzékelhetőek. Különösen most, hogy a felsőoktatási intézményrendszer újjászervezése kormányzati prioritássá vált, érzékelhetö, hogy e hálózatban bizonytalan csomópontok vannak (gondoljunk a kisméretű intézményekre), továbbá esetenként „gyenge szálak” mutathatóak ki, amennyiben az intézmények jelentős gazdasági, társadalmi meghatározó tényezők- 
höz (ágazati, iparági centrumokhoz, jelentős regionális szereppel rendelkezö önkormányzatokhoz) nem kapcsolódnak.

A pedagógusképzés történeti előzményeit szemlélve, $s$ a jelenlegi helyzetet érzékeltetve, két összefüggésre feltétlenül utalni kell. Elsőként arra, hogy a bolognai rendszerü mesterképzés meghonosításával a korábbiakhoz képest átalakult és számottevően bővült a képzési kínálat. Ez a változás kockázatot is jelentett, mivel egy olyan évtizedben játszódott le, amikor a pedagógusképzés vonzereje csökkent, a hallgatói létszámok az előző időszakhoz mérten számottevően visszaestek, különösen a természettudományos, metafizikai és müszaki tanárképzésben. A másik jellemző, hogy a pedagógusképzés több intézményében a szakképzési és felnőttképzési rendszer újabb képzési igényei alapján jelentős szakirányú továbbképzési programkínálat-bővítés valósult meg.

2009-ben fogalmazódott meg az a központi szakmapolitikai kezdeményezés, amely felismerve e képzési kínálatbővülési folyamat komplex jellegét, kísérletet tett egy, a hazai pedagógusképzés teljes intézményi rendszerét átfogó fejlesztési program kidolgozására, amely a „rendezetlenből” a rendezett állapot irányába mutató kezdeményezéseket és projektkonstrukciót eredményezett. ${ }^{4} E$ projektkezdeményezés hosszabb távra érvényes stratégiai célokat tüzött ki. Elsőként megfogalmazta a pedagógusképző intézmények regionális szolgáltató- és kutatóközpontjai kialakításának feladatát, melynek eredményeként 2011-re létre is jöttek azok a szervezeti és együttmüködési keretek, melyek új alapokra és kooperációs keretekbe szervezték a pedagógusképzés korszerüsítésével kapcsolatos helyi-regionális munkálatokat. A stratégia ugyanakkor ennél lényegesen tágabb együttmüködési formát is megfogalmazott célként: a regionális szolgáltató- és kutatóközponthoz kapcsolódó hálózati együttmüködés kialakitása, melynek lényegi, de csupán nyitóaktusának tekinthető a pedagógusképző intézmények regionális központjai közötti országos szolgáltató- és kutatóhálózat létrehozása. E folyamat eredményeként, feltételezhetően éppen évtizedünkben, s az új törvényi szabályozás által gyorsítva, létrejöhet egy magasabb szintü együttműködés a pedagógusképzésben részt vevő intézmények között, különös tekintettel a gyakorlatra jelentkező hallgatók és a közoktatási, szakképzési gyakorlóhelyek párosítására és elosztására alkalmas adatbázisok és informatikai alkalmazások fejlesztésében.

A 2009-2011 között megvalósult projekt főbb tevékenységei a következők voltak:

- a pedagógusképző intézmények regionális szolgáltató- és kutatóközpontjának kialakítása;

- a regionális szolgáltató- és kutatóközponthoz kapcsolódó hálózati együttműködés kialakítása;

\footnotetext{
${ }^{4}$ Konkrét példánk esetében a TAMOP 4.1.2-08/2/B projektek arra törekedtek, hogy együttmüködés jöjjön létre a közoktatási intézményekben a gyakorlatot vezető mentorok kiválasztására és felkészítésére vonatkozó módszertan kidolgozásában.
} 
- a pedagógusképző intézmények regionális központjai között országos szolgáltató- és kutatóhálózat létrehozása;

- együttmüködés a gyakorlatra jelentkező hallgatók és a közoktatási, szakképzési gyakorlóhelyek párosítására és elosztására alkalmas adatbázisok és informatikai alkalmazások fejlesztésében;

- együttműködés a közoktatási intézményekben a gyakorlatot vezető mentorok kiválasztására és felkészítésére vonatkozó módszertan kidolgozásában, a régióközpont szolgáltatási területén a mentorképzés megszervezése, indítása, minőségbiztosítása, a képzett mentorokról regionális nyilvántartás vezetése;

- a központok regionális minőségbiztosítási rendszerének kiépítése;

- a pedagógusképzésben foglalkoztatott oktatók felkészítése a kompetencia alapú pedagógiai munkára;

- az egyes tanári mesterképzésekben azonos szakmai tanári szakképzettséget nyújtó intézmények oktatói fórumainak és egyeztetett képzési dokumentumainak létrehozása;

- a pedagógusképzésben, illetve a szakirányú és egyéb továbbképzésben az oktatói munka feltételrendszerének javítása;

- az interkulturális oktatáshoz, a sajátos nevelési igényü tanulók integrált oktatására való érzékenyítéshez kapcsolódó pedagógiai módszerek fejlesztése.

A fejlesztés orientációs keretét a szakmai tanárképzésben meghonosodó hálózati szemlélet adta. A projekt a pedagógusképző intézményeket olyan „tanulásra” késztette, amelyben a formális és informális szakmai kommunikációt egyaránt támogató hálózatban az elektronikus eszközökkel támogatott információcsere egyre nagyobb szerepet kapott. E koncepció lényege a hálózati részvétel és az információkhoz jutás, valamint hozzáférés az információk értelmezését kontextusba helyező szoftverekhez, ami lehetöséget ad az együttmüködő és önszervező tanulásra. Ennek megfelelően a hazai projektmunkálatok egyik kitüntetett iránya, hogy a pedagógusképzés intézményei és partnerei körében is új típusú hálózatot építsenek ki, új (tudást) csomópontokat és éleket (müködő kapcsolatokat) hozzanak létre. E felfogás szerint középpontban az egyének és a tanulás hálózata áll. Figyelembe veszik az a felismerést, hogy a pedagógiai innovációs potenciál erősödését korlátozza a tanárképző intézmények, illetve oktatóik és kutatóik közötti kapcsolat esetleges, változó intenzitása.

A BME szakmai tanárképzési projektje hálózat alapú tanulást s közvetve a - hazai oktatásfejlesztési törekvésekben is jelenlévő - konnektivista paradigmát is érvényesítette ${ }^{5}$ E megközelítés a szervezeti tanulásra is adaptálható módon olyan $k \ddot{o}-$

\footnotetext{
${ }^{5}$ A Budapesti Műszaki és Gazdaságtudományi Egyetem Alkalmazott Pedagógiai és Pszichológiai Intézet az Új Magyarország Fejlesztési Terv Társadalmi Megújulás Operatív Program támogatási rend-
} 
zösségi hálózatfejlesztési folyamatnak tekinti a tanulást, melyben érvényesithetök a következö elvek:

- A tanulás és a tudás a vélemények különbözőségében rejlik, mely felismerés a szakmai viták, vélemények formálását egy olyan közösségi információcseréhez kapcsolja, melynek színterei a tanórai foglalkozások és a virtuális fórumok egyaránt lehetnek. Így e tevékenység időtartamának növekedése és differenciált formáinak bővülése komoly tanulási potenciált jelent.

- A tanulás olyan folyamat, melynek során a specializált csomópontokat, például az intézményeket, programokat, tanári közösségeket, kiemelkedő tanári egyéniségeket, mint lényeges információforrásokat konkrét „elérési közelségbe" hozzuk, a tanuló személyéhez, a tanulók közösségéhez kapcsoljuk.

A szakmai pedagógusképzők mellett kiemelkedő jelentőségủ számunkra az Eötvös Loránd Tudományegyetem Pedagógiai és Pszichológiai Kar (ELTE PPK) szakmai partnersége, különösen a hálózati müködés kiszélesítésében, a mentor kiválasztásban és mentorképzésben, valamint a továbbképzési témákban várható szinergiák miatt. A BME és az ELTE PPK megállapodás egyik fontos eleme a párhuzamos, redundáns fejlesztések elkerülése, a másik, a korszerü infokommunikációs technológiával (IKT) támogatott szolgáltatások egyeztetett fejlesztési folyamatban történő kifejlesztése és használhatósága mind a szakmai, mind a közismereti pedagógusképzésben. Az együttmüködés lényege az volt, hogy a fejlesztések során a partnerek bevonják egymást a szakértői munkákba, felajánlják egymásnak fejlesztéseik eredményeit, kiemelten a szakmai és a közismereti tanárképzés gyakorlati és mentorképzési területein.

A szakmai pedagógusképzést segítő szolgáltató- és kutatóhálózat kialakítása során 35 intézménnyel alakult ki hálózati együttmüködés, amely a szakmai információcserén túl lehetővé teszi hosszabb távon a pedagógusképzésben részt vevő hallgatók intézményi gyakorlatának differenciált - az egyéni szakmai igények és a különböző szakképzési szintek szerinti - szervezését és támogatását. Ehhez szorosan kapcsolódva valósult meg a felsőoktatási intézmények oktatóinak célirányos továbbképzése és az iskolai színtereken tevékenykedő mentor-tanárok szakirányú továbbképzési rendszerének kialakítása. A fejlesztések során az új módszertan kialakítása mellett és az új képzési modulok kidolgozásán túl a minőségorientált képzési rendszerben lényeges feladat volt a részt vevő intézmények és szakemberek, továbbá a gyakorlati képzésbe bekapcsolódók között olyan hálózati együttmüködés létrehozása, mely korszerú szemléletet alakít ki a szakmai pedagógusok körében.

szeréhez benyújtott pályázata „A szakmai pedagógusképzést segítő szolgáltató és kutatóhálózatok kialakítása" címmel nyert támogatást a Közép-magyarországi Régióban. 
Ez a modell a kockázat és megbizhatóság elemzésére épült. A szakképzés minőségbiztosításának folyamata több tudásterülettel is kapcsolatban van. Az általános pedagogikum mellett a szaktárgyak és szakmódszertan, valamint a szakmai gyakorlat olyan tevékenységek, melyek általában ismétlődnek a képzésben. A projekt keretében e tevékenységeket és speciális folyamatokat egymástól elkülönítettük, ugyanakkor meghatározott kapcsolódási felületekkel rendelkező elemekként kezeltük. A szakképzésben a minőségellenőrzés végrehajtása alapvetően a képzés eredményeinek követését, megfigyelését jelenti. Lényeges kritérium, hogy a hallgatók teljesítsék a minőségügyi követelményeket. A minőségellenőrzés részét képezik azok az intézkedések, amelyeknek célja a gyenge teljesítés okainak kiküszöbölése. Ezért a fejlesztés alapfelvetése, hogy a szakmai pedagógusképzésben és továbbképzésben részt vevő hallgatók között aktív kapcsolódási pontok jöjjenek létre, s az így formálódó tudásközvetítő hálózatban érvényesüljön Barabási által megfogalmazott gondolat, mely szerint a természetesen fejlődő rendszerekben a kapcsolatok nem véletlenül alakulnak ki, az újonnan érkezők jellemzően a korábbi központokhoz kapcsolódnak.

A szakmai pedagógusképzés sok évtizedes eddigi sikeres tapasztalataira és a jelentős közoktatási vezető populáció statisztikai elemzésére építve a BME-n formálódik egy, a jövőben rendszerszerüen használható minőségmenedzsment modell, $\mathrm{s}$ az ehhez szükséges szabályozási, támogatási, módszertani környezet kialakítása. A formálódó minőségmenedzsment modell alkalmazása során olyan visszacsatolási rendszer kialakítására is sor kerül, mely alkalmas számos, a képzés fejlesztésével kapcsolatos kérdés megválaszolására, többek között a következőkre: A hallgatók mely elvárásai meghatározóak a képzés szempontjából? Az oktatók mely elvárásai meghatározóak a képzés szempontjából? Vannak-e kapcsolódási pontok a hallgatók és az oktatók elvárásai között? A kialakításra kerülő minőségmenedzsment modell alkalmazása során olyan visszacsatolási lehetőség jön létre, melyben a minőségmenedzsment modell megfelelő statisztikai adatelemzési háttérrel rendelkezik. E modell, releváns szakmai válaszok esetében, képes segíteni a képzési célok, módszerek és formák, valamint a közvetített tartalmak, a fejlesztésre kerülő kompetenciák kialakítását, s ezzel a lehetséges fejlesztési irányokat és prioritásokat meghatározni, a szükséges és kapcsolódó szakmai döntések elökészítését támogatni.

\section{Összegzés helyett}

Írásunk arra vállalkozott, hogy általános keretekbe helyezze a pedagógusképzés jelenleg ellentmondásosan formálódó rendszerét, s e keretekben érzékeltesse a szakmai pedagógusképzés sajátosságait. Arra törekedtünk, hogy a rendszerezés ne csupán statikus leírást adjon, hanem ösztönözze - ha kell, vitákat is vállalva - a progreszszív gondolkodást. A jelenlegi átalakulási folyamat ellentmondásos elemeinek bemutatásán túl, a jelenlegi fejlesztési folyamat egyik markáns elemére, a minőség- 
menedzsment problematikájára, mint szemléletformáló rendszerelemre hívtuk fel a figyelmet egy szakmai tanárképzést fejlesztő projekthez kötődően. Mindezzel talán újabb megközelítések megfogalmazására is ösztönözzünk olvasóinkat, illetve szemléltetjük, hogy van bőven tenni való a pedagógusképzés nagy rendszerében...

\section{Irodalom}

Barabási-Albert László (2008): Behálózva. A hálózatok új tudománya. Helikon, Budapest.

Benedek András, Hunyady Györgyné (szerk., 2009): „Az oktatás közügy”. VII. Nevelésügyi Kongresszus. Magyar Pedagógiai Társaság, Budapest.

Benedek András, Szabóné Berki Éva (2010): Hálózatfejlesztés és innováció a szakmai pedagógusképzésben. In.: Kozma Tamás - Perjés István (szerk.): Új kutatások a neveléstudományokban 2010. Törekvések és lehetöségek a 21. század elején. Az MTA Neveléstudományi Bizottságának sorozata. ELTE Eötvös Kiadó, Budapest. 37-44.

Coombs, Ph. H. (1971): Az oktatás világválsága. Tankönyvkiadó, Budapest.

Csermely Péter, Fodor István, Eva Joly, Lámfalussy Sándor (2009): SZÁRNY ÉS TEHER. Ajánlás a nevelés-oktatás rendszerének újjáépitésére és a korrupció megfékezésére. Bölcsek Tanácsa Alapítvány, Budapest.

Deming, W. E. (1982): Out of the Crisis, MIT, Cambridge.

Fazekas Károly, Köllő János, Varga Júlia (szerk., 2008): Zöld könyv a magyar közoktatás megújitásáért. Ecostat, Budapest.

Lőrincz Éva Anna (2009): Új lehetőségek a szakmai képzés fejlesztésére. Szakképzési Szemle, 2. sz. 226-235.

Szabóné Berki Éva (2010): A Budapesti Müszaki és Gazdaságtudományi Egyetem innovációja a szakmai pedagógusképzésben. Szakképzési Szemle, 2. sz. 182-190.

Tenner, A. R., DeToro, I. J. (1996): Teljes körü minöségmenedzsment - TQM. Müszaki Könyvkiadó, Budapest. 